\title{
PENDIDIKAN MULTIKULTURAL UNTUK MEMBANGUN BANGSA YANG NASIONALIS RELIGIUS
}

\author{
R. Ibnu Ambarudin \\ Madrasah Tsanawiyah Wates Yogyakarta
}

\begin{abstract}
Indonesia is a multicultural country, multiethnic, multi-religious, and multi other things spreaded in the world. Therefore, it needs a wise, appropriate, and effective ways to respond so that the steps taken are not slipped ways and consequently endanger the sustainability of the nation in the future. Multicultural education is required by Indonesia to reduce the occurrence of horizontal conflicts between communities, because of differences in culture, ethnicity, customs, and religion is the emphasizing on learning to appreciate differences and not be regarded as causes of fragmentation. This can be done through selection of suitable material or nuanced tolerance towards all humans in the frame of together and do not emphasize the difference because of the spirit of ideology or their respective groups. Conceptually many religions and beliefs in the shades of multicultural are expected to bring about harmonious relationship, but in the implementation phase are still a lot of gaps between the expectation and realization due to some exclusive-uninded people still in multicultural society.
\end{abstract}

\section{Keywords: Multicultural Education, Nation of Building, nationalist religious, Religious Education}

\section{PENDAHULUAN}

Sebagai bangsa yang besar seperti jumlah penduduk yang sangat banyak, kekayaan alam yang melimpah, wilayah yang sangat luas, serta kekayaan budaya dan bahasa yang sangat beragam, Indonesia memiliki potensi yang sangat besar dan sekaligus juga memiliki permasalahan yang besar pula. Artinya Indonesia di samping besar potensi positifnya, besar pula potensi negatif atau permasalahanpermasalahan yang dihadapi. Dengan kata lain, kebesaran Indonesia adalah anugerah Tuhan sebagai manifestasi maha Pemurah dan sekaligus menjadi masalah yang diperlukan kearifan dalam menghadapinya. Indonesia merupakan negara kepulauan terbesar di dunia yang sangat plural, baik ditinjau dari suku bangsa, ras, bahasa, adat istiadat, seni budaya, agama dan aliran kepercayaan. Atas dasar kenyataan di atas, Indonesia rentan terhadap konflik internal yang bernuansa SARA (Suku, Agama, Ras, dan Antar golongan) maka dipandang perlu adanya suatu sistem pendidikan yang dapat memberikan solusi alternatif bagi seluruh kebutuhan dan tuntutan dari masyarakat Indonesia.

Kondisi masyarakat yang plural baik dari segi budaya, ras, agama, dan status sosial ekonomi cenderung untuk menimbulkan potensi benturan bernuansa 
SARA termasuk nilai-nilai yang berlaku di dalam masyarakat. Oleh karena itu dipandang perlu adanya suatu pendidikan multikultural dalam sistem pendidikan nasional Indonesia agar peserta didik dapat memiliki kepekaan dalam menghadapi gejala-gejala atau permasalahan-permasalahan sosial yang terjadi akibat perbedaan dan tata nilai yang terjadi pada lingkungan masyarakat. Apabila hal ini tidak segera diatasi, maka konflik sosial yang sering terjadi di Indonesia dan tidak jarang dilakukan dalam bentuk kekerasan fisik dapat berpotensi mengancam persatuan, kesatuan, serta keutuhan bangsa. Walaupun konflik itu akan selalu terjadi, karena merupakan realitas permanen dalam perubahan suatu kehidupan, akan tetapi konflik tersebut tidak boleh dibiarkan berkembang yang berpotensi merusak tatanan kehidupan bermasyarakat, berbangsa, dan bernegara. Dengan demikian perlu digulirkan paradigma baru baik melalui sistem politik yang mampu mengendalikan konflik maupun melalui jalur pendidikan yang mampu mengayomi dan menyadarkan seluruh lapisan masyarakat dengan tidak membedakan latar belakang mereka.

Dalam perjalanan panjang sejarah Indonesia, realitas kehidupan berbangsa dan bernegara, masalah kesatuan dan persatuan bangsa telah mengalami pasang surut yang cukup melelahkan dan menguras energi potensial bangsa ini. Polemik Natsir-Soekarno pada masa pra kemerdekaan, tentang hubungan agama dan negara adalah satu contoh nyata sebagai sebuah realitas sejarah bangsa ini (Suhelmi:1999). Polemik tersebut merefleksikan pencarian bentuk negara dan sekaligus pertarungan ideologis yang amat tajam antara kubu nasionalis sekuler dan kubu Islam politik yang sampai hari ini masih menjadi perbincangan yang hangat. Pada masa awal kemerdekaan dan masa orde lama juga telah terjadi pertarungan-pertarungan ideologis yang tak jarang berakhir dengan kontak senjata dan peristiwa-peristiwa berdarah yang hingga saat ini masih diselimuti awan kelabu (Wieringa:1999). Bahkan lebih tragis lagi ada komponen bangsa yang tidak dapat mengenyam kebebasan berpolitik termasuk melaksanakan ajaran agamanya. Sampai pada akhir rezim orde baru juga banyak yang mengalami tekanan dari penguasa yang pada waktu itu menggunakan paham otoriter militerisme. 
Banyaknya persoalan yang muncul di tanah air terutama dari aspek sosial, budaya, dan agama disinyalir disebabkan oleh lemahnya peran pendidikan dalam melakukan penanaman atau inkulkasi nilai kebaikan bersama yang seharusnya menjadi roh bangsa ini. Peristiwa-peristiwa seperti konflik antar ras, agama, suku, golongan, perebutan kekuasaan di berbagai daerah adalah bukti nyata bahwa pemahaman terhadap nilai kebersamaan masih lemah. Konflik merupakan cerminan kehidupan manusia yang tidak konsisten dalam memperjuangkan kebenaran, kebaikan, serta keadilan, dan juga sebagai cerminan dari ketidakmampuan manusia dalam membangun hubungan yang harmonis dengan sesama, alam lingkungan, dan Tuhan.

Konflik dan kekerasan terjadi di berbagai wilayah Indonesia disebabkan karena tidak saling memahami dan menghargai antar kelompok satu dengan kelompok lainnya. Padahal dalam realitas plural atau multikultural seperti Indonesia, yang terpenting diperhatikan dalam kehidupan adalah bagaimana satu kelompok dapat hidup berdampingan secara harmonis dengan kelompok atau keyakinan yang lain dan menjunjung tinggi nilai-nilai pluralitas universal atau dalam konteks ke-Indonesiaan berbhineka tunggal ika. Hal ini tidak tampak atau paling tidak semakin menurun kualitasnya dalam kehidupan bangsa dan berbangsa di Indonesia. Dialog antar budaya dan agama yang sering diadakan oleh para tokoh agama dari berbagai keyakinan seolah-olah kurang membuahkan hasil yang signifikan kalau tidak dikatakan tidak menghasilkan sesuatu hal yang diharapkan secara ideal. Bahkan semakin sering pula terjadi kekerasan dan konflik sosial dan horizontal yang pada akhirnya tanpa disadari nilai-nilai universal tersebut tidak tampak dalam kehidupan masyarakat. Sebagian ada yang mengatakan bahwa kekerasan dilakukan karena menjalankan kewajiban berdasarkan perintah Tuhan, agama, dan atau atas nama jihad untuk membela "kebenaran". Oleh karena itu doktrin mati syahid karena perjuangan yang ditanamkan atau tertanam dalam diri seseorang membuat pemahaman tentang realitas plural di tanah air kurang, terabaikan atau bahkan tidak diindahkan lagi.

\section{Pengertian Multikulturalisme dan Pendidikan Multikultural}

Multikulturalisme mengandung dua pengertian yang sangat kompleks yaitu "multi" yang berarti plural, "kulturalisme" berisi pengertian budaya. Istilah plural 
mengandung arti yang berjenis-jenis, karena pluralisme bukan berarti sekedar pengakuan akan adanya hal-hal yang berjenis-jenis, tetapi juga pengakuan tersebut mempunyai implikasi-implikasi politis, sosial, dan ekonomi. Oleh sebab itu, pluralisme berkaitan dengan prinsip-prinsip demokrasi dalam tata dunia atau masyarakat yang etis. Banyak negara yang menyatakan dirinya sebagai negara demokrasi, tetapi tidak mengakui adanya pluralisme di dalam kehidupannya, sehingga terjadi berbagai jenis segregasi. Pluralisme ternyata berkenaan dengan hak hidup kelompok-kelompok masyarakat yang ada dalam suatu komunitas. Komunitas-komunitas tersebut mempunyai budayanya masing-masing yang jelas berbeda satu dengan yang lain (Muhadjir:2000).

Dalam sejarahnya, pendidikan multikultural sebagai sebuah konsep atau pemikiran tidak muncul dalam ruangan kosong, namun ada interest politik, sosial, ekonomi, dan intelektual yang mendorong kemunculannya. Wacana pendidikan multikultural pada awalnya sangat bias Amerika karena punya akar sejarah dengan gerakan Hak Asasi Manusia dari berbagai kelompok yang tertindas di negeri tersebut. Banyak lacakan sejarah atau asal-usul pendidikan multikultural yang merujuk pada gerakan sosial orang Amerika keturunan Afrika dan kelompok kulit berwarna lain yang mengalami praktik diskriminasi di lembaga-lembaga publik pada masa perjuangan hak asasi pada tahun 1960-an. Di antara lembaga yang secara khusus disorot karena bermusuhan dengan ide persamaan ras pada saat itu adalah lembaga pendidikan. Pada akhir 1960-an dan awal 1970-an, suarasuara yang menuntut lembaga-lembaga pendidikan agar konsisten dalam menerima dan menghargai perbedaan semakin kuat yang dikumandangkan oleh para aktivis, para tokoh, dan orang tua. Mereka menuntut adanya persamaan kesempatan di bidang pekerjaan dan pendidikan. Momentum inilah yang dianggap sebagai awal mula dari konseptualisasi pendidikan multikultural. Konsep pendidikan multikultural yang dianut oleh negara-negara demokratis seperti Amerika Serikat dan Kanada telah mengalami perjalanan panjang dan sudah menemukan jatidirinya.

Pendidikan multikultural merupakan proses pengembangan sikap dan tata laku seseorang atau sekelompok orang dalam usaha mendewasakan manusia melalui upaya pengajaran, pelatihan, proses, perbuatan, dan cara-cara mendidik 
yang menghargai pluralitas dan heterogenitas secara humanistik. Pendidikan multikultural mengandung arti bahwa proses pendidikan yang diimplementasikan pada kegiatan pembelajaran di satuan pendidikan selalu mengutamakan unsur perbedaan sebagai hal yang biasa, sebagai implikasinya pendidikan multikultural membawa peserta didik untuk terbiasa dan tidak mempermasalahkan adanya perbedaan secara prinsip untuk bergaul dan berteman dengan siapa saja tanpa membedakan latar belakang budaya, suku bangsa, agama, ras, maupun adat istiadat yang ada. Banks (2007: 83-84) mengidentifikasi ada lima dimensi pendidikan multikultural yang diperkirakan dapat membantu guru dalam mengimplementasikan beberapa program yang mampu merespon terhadap perbedaan pelajar, yaitu:

\section{Dimensi Integrasi Isi atau Materi (content integration)}

Dimensi ini digunakan oleh guru untuk memberikan keterangan dengan hal-hal penting dalam pembelajaran dengan merefleksikan materi yang berbedabeda. Secara khusus, para guru menggabungkan kandungan materi pembelajaran ke dalam kurikulum dengan beberapa cara pandang yang beragam. Salah satu pendekatan umum adalah mengakui kontribusinya, yaitu guru-guru bekerja ke dalam kurikulum mereka dengan membatasi fakta tentang semangat kepahlawanan dari berbagai kelompok.

Dengan beberapa pendekatan, guru menambah beberapa unit atau topik secara khusus yang berkaitan dengan materi multikultural. Dengan kata lain adalah upaya untuk mengintegrasikan pendidikan multikultural dalam kurikulum atau bagian dalam kurikulum integrasi tersebut ditempatkan. Isi kurikulum tersebut antara lain, berkaitan dengan masalah bagaimana mengurangi berbagai prasangka dalam perlakuan dan tingkah laku rasial dari etnis-etnis tertentu dan di dalam materi apa prasangka-prasangka tersebut dapat dikemukakan. Di dalam kaitan ini, diperlukan studi mengenai jenis-jenis kebudayaan dari kelompokkelompok etnis. Dalam kaitan ethnic studies movement sejak tahun 1960-an di Amerika Serikat, termasuk di dalam gerakan ini adalah menulis dan mengumpulkan sejarah dari masing-masing kelompok etnis yang ada di dalam masyarakat. 


\section{Dimensi Konstruksi Pengetahuan (knowledge construction)}

Dimensi yang mengharuskan agar para guru membantu siswa untuk memahami beberapa perspektif dan merumuskan kesimpulan yang dipengaruhi oleh disiplin pengetahuan yang mereka miliki. Dimensi ini juga berhubungan dengan pemahaman para pelajar terhadap perubahan pengetahuan yang ada pada diri mereka sendiri.

\section{Dimensi Pengurangan Prasangka (prejudice reduction)}

Guru melakukan banyak usaha untuk membantu siswa dalam mengembangkan perilaku positif tentang perbedaan kelompok. Kondisi yang dimaksud adalah bahan pembelajaran yang memiliki citra yang positif tentang perbedaan kelompok dan menggunakan bahan pembelajaran tersebut secara konsisten dan terus-menerus. Penelitian menunjukkan bahwa para pelajar yang datang ke sekolah dengan banyak stereotip, cenderung berperilaku negatif dan banyak melakukan kesalahpahaman terhadap kelompok etnis dan ras dari luar kelompoknya. Penelitian juga menunjukkan bahwa penggunaan textbook multikultural atau bahan pengajaran lain dan strategi pembelajaran yang kooperatif dapat membantu para pelajar untuk mengembangkan perilaku dan persepsi terhadap ras yang lebih positif. Jenis strategi dan bahan dapat menghasilkan pilihan para pelajar untuk lebih bersahabat dengan ras luar, etnis, dan kelompok budaya lain.

\section{Dimensi Pendidikan yang Sama/Adil (equitable pedagogy)}

Dimensi ini memperhatikan cara-cara dalam mengubah fasilitas pembelajaran sehingga mempermudah pencapaian hasil belajar pada sejumlah siswa dari berbagai kelompok. Strategi dan aktivitas belajar yang dapat digunakan sebagai upaya memperlakukan pendidikan secara adil, antara lain dengan bentuk kerja sama, dan bukan dengan cara-cara yang kompetitif (competition learning). Dimensi ini juga menyangkut pendidikan yang dirancang untuk membentuk lingkungan sekolah, menjadi banyak jenis kelompok, termasuk kelompok etnis, wanita, dan para pelajar dengan kebutuhan khusus yang akan memberikan pengalaman pendidikan persamaan hak dan persamaan memperoleh kesempatan belajar. 


\section{Dimensi Pemberdayaan Budaya Sekolah dan Struktur Sosial (empowering school culture and social structure)}

Dimensi ini penting dalam memperdayakan budaya siswa yang dibawa ke sekolah yang berasal dari kelompok yang berbeda. Di samping itu, dapat digunakan untuk menyusun struktur sosial (sekolah) yang memanfaatkan potensi budaya siswa yang beranekaragam sebagai karakteristik struktur sekolah setempat, misalnya berkaitan dengan praktik kelompok, iklim sosial, latihanlatihan, partisipasi ekstra kurikuler, dan penghargaan staff dalam merespon berbagai perbedaan yang ada di sekolah. Keempat pendekatan tersebut di atas semuanya bermuara kepada pemberdayaan kebudayaan sekolah. Apabila pendekatan-pendekatan pendidikan multikultural tersebut di atas dapat dilaksanakan, maka dengan sendirinya lahir kultur sekolah yang kuat dalam menghadapi masalah-masalah sosial dalam masyarakat. Sekolah merupakan lembaga yang akan menjadi suatu motor penggerak dalam perubahan struktur masyarakat yang timpang karena kemiskinan atau pun tersisih dalam budaya "mainstream" masyarakat.

\section{Sejarah Pendidikan Multikultural}

Pandangan multikulturalisme dalam masyarakat Indonesia dalam praktik kenegaraan belum dijalani sebagaimana mestinya. Lambang Bhinheka Tunggal Ika, yang bermakna keragamaan dalam kesatuan ternyata yang ditekankan hanyalah kesatuannya dan mengabaikan keragaman budaya dan masyarakat Indonesia. Hal ini telah terjadi pada masa orde baru yang menunjukkan relasi masyarakat terhadap praktik hidup kenegaraan tersebut, ternyata masyarakat kita ingin menunjukkan identitasnya sebagai masyarakat bhineka yang selama Orde Baru telah ditindas dengan berbagai cara demi untuk mencapai kesatuan bangsa. Demikian pula praksis pendidikan sejak kemerdekaan sampai era Orde Baru telah mengabaikan kekayaan kebhinhekaan kebudayaan Indonesia yang sebenarnya merupakan kekuatan dalam suatu kehidupan demokrasi.

Sejak jatuhya presiden Suharto dari kekuasaannya, yang kemudian diikuti dengan masa yang disebut era reformasi, Indonesia mengalami disintregasi, krisis moneter, ekonomi, politik, dan agama yang mengakibatkan terjadinya krisis multi dimensi di dalam kehidupan berbangsa dan bernegara. Pada era reformasi 
pendidikan masih dapat dikatakan belum memperoleh sistem terbaik dan masih hanya dinikmati oleh kelompok tertentu. Dengan kata lain pendidikan multikultural belum dianggap penting walaupun realitas kultur dan agama sangat beranekaragam.

\section{Pendidikan Multikultural di Indonesia}

Wacana multikulturalisme dalam konteks Indonesia menemukan momentumnya ketika sistem nasional yang otoriter-militeristik tumbang seiring dengan jatuhnya rezim Soeharto. Saat itu, keadaan negara menjadi kacau yang ditandai dengan berbagai konflik antarsuku bangsa dan antar golongan yang menimbulkan ketidaknyamanan bagi masyarakat. Kondisi yang demikian membuat berbagai pihak semakin mempertanyakan kembali sistem nasional seperti apa yang cocok bagi Indonesia yang sedang berubah, serta sistem apa yang dapat membuat masyarakat Indonesia hidup damai dengan meminimalisir potensi konflik. Multikulturalisme adalah konsep yang dianggap mampu menjawab tantangan perubahan zaman dengan alasan multikulturalisme merupakan sebuah ideologi yang mengagungkan atau mengusung perbedaan budaya, atau sebuah keyakinan yang mengakui dan mendorong terwujudnya pluralisme budaya sebagai corak kehidupan masyarakat. Multikulturalisme akan menjadi pengikat dan jembatan yang mengakomodasi perbedaan-perbedaan termasuk perbedaan suku bangsa dalam masyarakat yang multikultural. Didorong oleh tuntutan warga Amerika keturunan Afrika, Latin/Hispanic, warga pribumi, dan kelompok marginal lain terhadap persamaan kesempatan pendidikan serta didorong oleh usaha komunitas pendidikan profesional untuk memberikan solusi terhadap masalah pertentangan ras dan rendahnya prestasi kaum minoritas di sekolah menjadikan pendidikan multikultural sebagai slogan yang sangat populer pada tahun 1990-an. Selama dua dekade konsep pendidikan multikultural menjadi slogan yang sangat populer di sekolah-sekolah Amerika Serikat. Secara umum, konsep ini diterima sebagai strategi penting dalam mengembangkan toleransi dan sensitivitas terhadap sejarah dan budaya dari kelompok etnis yang beraneka macam di negara ini.

Ide pendidikan multikulturalisme akhirnya menjadi komitmen global sebagaimana direkomendasi UNESCO Oktober 1994 di Jenewa. Rekomendasi itu 
di antaranya pertama, pendidikan hendaknya mengembangkan kemampuan untuk mengakui dan menerima nilai-nilai yang ada dalam kebhinekaan pribadi, jenis kelamin, masyarakat dan budaya serta mengembangkan kemampuan untuk berkomunikasi, berbagi dan bekerja sama dengan yang lain. Kedua, pendidikan hendaknya meneguhkan jati diri dan mendorong konvergensi gagasan dan penyelesaian-penyelesaian yang memperkokoh perdamaian, persaudaraan dan solidaritas antara pribadi dan masyarakat. Ketiga, pendidikan hendaknya meningkatkan kemampuan menyelesaikan konflik secara damai dan tanpa kekerasan. Karena itu, pendidikan hendaknya juga meningkatkan pengembangan kedamaian dalam diri pikiran peserta didik sehingga dengan demikian mereka mampu membangun secara lebih kokoh kualitas toleransi, kesabaran, kemauan untuk berbagi dan memelihara.

Konsep pendidikan multikultural dalam perjalanannya menyebar luas ke kawasan di luar Amerika khususnya di negara-negara yang memiliki keragaman etnis, ras, agama, dan budaya seperti Indonesia. Pada saat ini, pendidikan multikultural secara umum mencakup ide pluralisme budaya dan agama. Tema umum yang dibahas meliputi pemahaman budaya, penghargaan budaya dari kelompok yang beragam dan persiapan untuk hidup dalam masyarakat pluralistik. Paradigma pendidikan multikulturalisme sangat bermanfaat untuk membangun kohesivitas, soliditas, dan intimidasi di antara keragaman etnis, ras, agama, budaya, dan berbagai hal yang lain di antara kita. Permasalahan di atas juga memberi dorongan dan spirit bagi lembaga pendidikan nasional untuk mau menanamkan sikap kepada peserta didik untuk menghargai orang, budaya, agama, dan keyakinan lain. Oleh karena itu diharapkan bahwa dengan implementasi pendidikan yang berwawasan multikultural, akan membantu siswa mengerti, menerima, dan menghargai orang lain yang berbeda suku, budaya, dan nilai kepribadian. Lewat penanaman semangat multikulturalisme di sekolah-sekolah, akan menjadi media pelatihan dan penyadaran bagi generasi muda untuk menerima perbedaan budaya, agama, ras, etnis, dan lainnya di antara sesama serta mau hidup bersama secara damai. Agar proses ini berjalan sesuai harapan, maka seyogianya kita mau menerima jika pendidikan multikultural disosialisasikan melalui lembaga pendidikan, bahkan apabila memungkinkan dapat ditetapkan 
sebagai bagian dari kurikulum pendidikan di berbagai jenjang dan jenis pendidikan. Pada konteks ini dapat dikatakan, tujuan utama dari pendidikan multikultural adalah untuk menanamkan sikap simpati, respek, apresiasi, dan empati terhadap penganut agama dan budaya yang berbeda. Lebih jauh lagi, penganut agama dan budaya yang berbeda dapat belajar untuk melawan atau setidaknya tidak setuju dengan ketidaktoleranan seperti pengadilan negara atas sah-tidaknya teologi atau ideologi, perang agama, diskriminasi, dan hegemoni budaya di tengah kultur monolitik dan uniformitas global. Pada era tahun 1980-an tampaknya merpakan era yang dianggap sebagai kemunculan lembaga sekolah yang berlandaskan pendidikan multikultural yang didirikan oleh para peneliti dan aktivis pendidikan progresif. James Bank adalah salah satu pioner dari pendidikan multikultural. yang mampu mengubah konsep pendidikan multikultural menjadi ide persamaan pendidikan bagi semua orang.

Pada konteks Indonesia, perbincangan tentang konsep pendidikan multikultural semakin memperoleh momentum pasca runtuhnya rezim otoritermiliteristik Orde Baru karena hempasan badai reformasi. Era reformasi ternyata tidak hanya membawa berkah bagi bangsa kita namun juga memberi peluang meningkatnya kecenderungan primordialisme. Untuk itu, dirasakan kita perlu menerapkan paradigma pendidikan multikultur untuk menangkal semangat primordialisme tersebut. Secara generik, pendidikan multikultural memang sebuah konsep yang dibuat dengan tujuan untuk menciptakan persamaan peluang pendidikan bagi semua siswa yang berbeda-beda ras, etnis, kelas sosial dan kelompok budaya. Salah satu tujuan penting dari konsep pendidikan multikultural adalah untuk membantu semua siswa agar memperoleh pengetahuan, sikap dan keterampilan yang diperlukan dalam menjalankan peran seefektif mungkin pada masyarakat demokrasi-pluralistik serta diperlukan untuk berinteraksi dan berkomunikasi dengan warga dari kelompok yang beragam agar tercipta sebuah tatanan masyarakat bermoral yang berjalan untuk kebaikan bersama.

Menurut H.A.R. Tilaar (2004) untuk membangun pendidikan multikultural di Indonesia membutuhkan beberapa dimensi, antara lain sebagai berikut:

1. Right to Culture dan identitas budaya lokal 
Multikulturalisme meskipun didorong oleh pengakuan terhadap hak asasi manusia, namun akibat globalisasi pengakuan tersebut diarahkan juga kepada hak-hak yang lain, yaitu hak akan kebudayaan (right to culture). Pendidikan multikultural di Indonesia haruslah diarahkan kepada terwujudnya masyarakat madani (civil society) di tengah-tengah kekuatan kebudayaan global.

2. Kebudayaan Indonesia

Kebudayaan Indonesia yang-menjadi adalah suatu Weltanschauung, artinya pegangan setiap insan dan setiap identitas budaya mikro Indonesia. Sebagai suatu Weltanschauung, hal tersebut merupakan suatu system nilai yang baru (value system). Sebagai suatu value system yang baru, memerlukan suatu proses perwujudannya antara lain melalui proses dalam pendidikan nasional. Oleh sebab itu, di tengah-tengah maraknya identitas kesukuan, sekaligus perlu ditekankan sistem nilai baru yang akan kita wujudkan, yaitu sistem nilai keindonesiaan. Hal tersebut bukannya suatu yang mudah karena memerlukan paradigm shift di dalam proses pendidikan bangsa Indonesia. Sebagai suatu paradigma baru di dalam sistem pendidikan nasional, maka perlu dirumuskan bagaimana pendidikan nasional diarahkan kepada pemeliharaan dan pengembangan konsep negara-bangsa, yaitu Negara Kesatuan Republik Indonesia (NKRI) yang didasarkan kepada kekayaan kebudayaan dari berbagai suku bangsa di Indonesia.

3. Konsep pendidikan multikultural normatif

Tujuan pendidikan multikultural normatif untuk mewujudkan kebudayaan Indonesia yang dimiliki oleh suatu negara-bangsa, tapi jangan sampai menjadikan konsep pendidikan multicultural normative sebagai suatu paksaan dengan menghilangkan keanekaragaman budaya-budaya lokal. Pendidikan multikultural normative, justru memperkuat identitas suatu suku yang kemudian dapat menyumbangkan bagi terwujudnya suatu kebudayaan Indonesia yang dimiliki oleh seluruh bangsa Indonesia. Konsep ini dengan sendirinya sesuai dengan tuntutan atas hak asasi manusia dan sekaligus hak untuk mempunyai dan mengembangkan budaya sendiri (right to culture). 
4. Pendidikan multikultural merupakan suatu rekonstruksi sosial

Suatu rekonstruksi sosial artinya upaya untuk melihat kembali kehidupan sosial yang ada dewasa ini. Salah satu masalah yang timbul akibat berkembangnya rasa kedaerahan, identitas kesukuan, the right to culture dari perorangan maupun suatu suku bangsa Indonesia, telah menimbulkan rasa kelompok yang berlebihan dan tidak jarang menyebabkan pergeseran dan tidak jarang menyebabkan pergeseran-pergeseran horizontal yang tidak dikenal sebelumnya. Rasa kesukuan yang berlebihan dapat melahirkan ketidakharmonisan dalam kehidupan bangsa yang pluralis. Oleh sebab itu, pendidikan multikultural tidak akan mengenal fanatisme atau fundamentalisme sosial-budaya termasuk agama, karena masing-masing komunitas mengenal dan menghargai perbedaan-perbedaan yang ada sehingga pendidikan multikultural di Indonesia memerlukan pedagogik baru.

Untuk melaksanakan konsep pendidikan multikultural di dalam masyarakat pluralis, memerlukan pedagogik baru, karena pedagogik tradisional membatasi proses pendidikan dalam ruang sekolah yang sarat dengan pendidikan intelektualistik. Sedangkan kehidupan sosial-budaya di Indonesia menuntut pendidikan hati (pedagogy of heart), yaitu diarahkan kepada rasa persatuan dari bangsa Indonesia yang pluralistik. Pedagogik yang dibutuhkan ialah: 1) Pedagogik pemberdayaan (pedagogy empowerment). 2) Pedagogik kesetaraan manusia dalam kebudayaan yang beragam (pedagogy of equity). Pedagogik pemberdayaan pertama-tama berarti, seorang mengenal budayanya sendiri dan selanjutnya kebudayaan itu digunakan untuk mengembangkan budaya Indonesia di dalam negara-bangsa Indonesia. Di dalam upaya tersebut diperlukan pedagogik kesetaraan antar-individu, antar suku, dan tidak membedakan asal-usul suku bangsa dan agamanya.

5. Pendidikan Multikultural bertujuan untuk masa depan serta etika berbangsa

Dalam TAP/MPR RI Tahun 2001 No. VI dan VII mengenai visi Indonesia masa depan, serta etika kehidupan berbangsa perlu dijadikan pedoman yang sangat berharga dalam mengembangkan konsep pendidikan multikultural. Dalam kaitan ini, perlu dipertimbangkan menghidupkan kembali pendidikan budi pekerti, terutama di tingkat pendidikan dasar, 
melengkapi pendidikan agama yang sudah ditangani dengan UU No. 20 Tahun 2003 (Tilaar:2007:185).

Pernyataan-pernyataan dan keyataan di atas adalah satu usaha dalam upaya membangun pendidikan multikultural di Indonesia sebagai sebuah negara yang plural. Hal ini membutuhkan satu konsep pendidikan multikultural yang dapat menghasilkan peserta didik yang dapat menghargai perbedaan dan hidup dalam keharmonisan perbedaan. Berikut beberapa pendekatan dalam proses pendidikan multikultural, yaitu:

Pertama, tidak lagi terbatas pada menyamakan pandangan pendidikan (education) dengan persekolahan atau pendidikan multikultural dengan programprogram sekolah formal. Pandangan yang lebih luas mengenai pendidikan sebagai transmisi kebudayaan membebaskan pendidik dari asumsi, bahwa tanggung jawab primer mengembangkan kompetensi kebudayaan di kalangan anak didik sematamata berada di tangan mereka dan justru semakin banyak pihak yang bertanggung jawab karena program-program sekolah seharusnya terkait dengan pembelajaran informal di luar sekolah.

Kedua, menghindari pandangan yang menyamakan kebudayaan dengan kelompok etnik adalah sama. Artinya, tidak perlu lagi mengasosiasikan kebudayaan semata-mata dengan kelompok-kelompok etnik sebagaimana yang terjadi selama ini. secara tradisional, para pendidik mengasosiasikan kebudayaan hanya dengan kelompok-kelompok sosial yang relatif self sufficient, ketimbang dengan sejumlah orang yang secara terus menerus dan berulang-ulang terlibat satu sama lain dalam satu atau lebih kegiatan. Dalam konteks pendidikan multikultural, pendekatan ini diharapkan dapat mengilhami para penyusun program-program pendidikan multikultural untuk melenyapkan kecenderungan memandang anak didik secara stereotip menurut identitas etnik mereka dan akan meningkatkan eksplorasi pemahaman yang lebih besar mengenai kesamaan dan perbedaan di kalangan anak didik dari berbagai kelompok etnik.

Ketiga, karena pengembangan kompetensi dalam suatu "kebudayaan baru" biasanya membutuhkan interaksi inisiatif dan intensif dengan orang-orang yang sudah memiliki kompetensi, bahkan dapat dilihat lebih jelas bahwa upaya-upaya untuk mendukung sekolah-sekolah yang terpisah secara etnik adalah antitesis 
terhadap tujuan pendidikan multikultural. Mempertahankan dan memperluas solidaritas kelompok akan menghambat sosialisasi ke dalam kebudayaan "baru" yang pada akhirnya harus disadari bahwa pendidikan bagi pluralisme budaya dan pendidikan multikultural tidak dapat disamakan secara logis walaupun memang harus dapat diterjemahkan secara praktis atau bahkan pragmatis.

Keempat, pendidikan multikultural meningkatkan kompetensi dalam beberapa kebudayaan. Dalam pengertian ini seorang pendidik harus mampu memilah dan memilih satu kebudayaan yang akan diadopsi serta ditentukan oleh situasi dan kondidsi yang paling mungkin. Dengan demikian tidak akan terkesan terlalu besar keinginan yang tidak dibarengi dengan melihat kemampuan atau kenyataan yang ada.

Kelima, kemungkinan bahwa pendidikan (baik dalam maupun luar sekolah) meningkatkan kesadaran tentang kompetensi dalam beberapa kebudayaan. Kesadaran seperti ini kemudian akan menjauhkan kita dari konsep dua budaya atau dapat diartikan dikotomi antara pribumi dan non-pribumi. Dikotomi semacam ini bersifat membatasi individu untuk sepenuhnya mengekspresikan diversitas kebudayaan. Dengan demikian pendekatan ini akan meningkatkan kesadaran tentang realitas multikulturalisme sebagai pengalaman normal dan normatif sebagai manusia. Kesadaran ini mengandung makna bahwa pendidikan multikultural berpotensi untuk menghindari dikotomi dan mengembangkan apresiasi yang lebih baik melalui kompetensi kebudayaan yang ada pada diri anak didik.

\section{Pengembangan Materi Pendidikan Agama Islam Berbasis Multikultural}

Menurut Zamroni (2007:273 - 274) dalam pendidikan agama agar tercipta kesadaran multikultural maka sekolah perlu memperhatikan beberapa hal, yaitu:

1. Pendidikan agama bersifat transformatif, artinya pendidikan agama harus mampu menumbuhkan perubahan yang menitik beratkan pada rasa dan suasana kebersamaan yang penuh dengan toleransi.

2. Dalam melaksanakan proses pembelajaran guru senantiasa bersifat reflektif yang mengedepankan sintesis atau memadukan materi pembelajaran dengan kondisi dan latar belakang yang ada khususnya murid. Guru juga harus mampu berdialog agar murid cakap dalam menganalisa berbagai 
permasalahan dan memberikan argumentasi balik dengan penuh sopan santun yang pada akhirnya akan menciptakan saling memahami perbedaan yang ada. Guru juga senantiasa bersifat Caring yang berarti menjadi orang tua yang baik penuh perhatian pada anak didik.

3. Pendidikan Agama juga harus dapat mengembangkan kesadaran pada anak didik hakikat masyarakat majemuk sehingga akan memunculkan kesadaran bahwa perbedaan merupakan rahmat dan juga akan menumbuhkan sifat toleransi yang tulus.

Dalam rangka membangun keberagamaan yang inklusif di sekolah ada beberapa materi pendidikan agama Islam yang bisa dikembangkan dengan nuansa multikultural, antara lain: Pertama, materi al-Qur'an, dalam menentukan ayat-ayat pilihan, selain ayat-ayat tentang keimanan juga perlu ditambah dengan ayat-ayat yang dapat memberikan pemahaman dan penanaman sikap ketika berinteraksi dengan orang yang berlainan agama, sehingga sedini mungkin sudah tertanam sikap toleran, inklusif pada peserta didik, yaitu a) materi yang berhubungan dengan pengakuan Al-Qur'an akan adanya pluralitas dan berlomba dalam kebaikan misalnya yang ada pada surat al-Baqarah ayat 148; b) Materi yang berhubungan dengan pengakuan koeksistensi damai dalam hubungan antar umat beragama missal dalam surat Al-Mumtahanah ayat 8 dan 9); c) materi yang berhubungan dengan keadilan dan persamaan seperti dalam an-Nisa': 135. Kedua, materi fikih dapat diperluas dengan kajian fikih siasah (pemerintahan) yang di dalamnya terkandung konsep-konsep kebangsaan yang telah dicontohkan pada zaman Nabi Muhammad maupun khalifah-khalifah sesudahnya. Pada zaman Nabi misalnya, cara Nabi mengelola dan memimpin masyarakat Madinah yang multietnis, multi-kultur, dan multi-agama. Keadaan masyarakat Madinah pada waktu itu tidak jauh berbeda dengan masyarakat Indonesia, yang juga multi-etnis, multikultur, dan multi-agama. Ketiga, materi akhlak yang memfokuskan kajiannya pada perilaku baik-buruk terhadap Allah, Rasul, sesama manusia, diri sendiri, serta lingkungan, penting artinya bagi peletakan dasar-dasar kebangsaan. Hal ini berangkat dari pernyataan normatif yang terbukti secara historis bahwa "keberlangsungan" suatu bangsa tergantung pada akhlak anak bangsa tersebut. Apabila suatu bangsa meremehkan akhlak, punahlah bangsa tersebut seperti yang 
dicontohkan dalam Al-Qur'an tentang kehancuran kaum Luth yang disebabkan oleh runtuhnya sendi-sendi moral warganya. Agar Pendidikan Agama bernuansa multikultural ini dapat efektif maka peran guru agama Islam memang sangat menentukan. Selain selalu mengembangkan metode mengajar yang variatif, tidak monoton dan yang lebih penting, guru agama Islam juga harus mampu menjadi model atau keteladanan. Keempat, materi SKI, materi yang bersumber pada fakta dan realitas historis dapat dicontohkan praktik-praktik interaksi sosial yang diterapkan Nabi Muhammad ketika membangun masyarakat Madinah. Dari sisi historis proses pembangunan Madinah yang dilakukan Nabi dapat ditemukan fakta tentang adanya pengakuan dan penghargaan atas nilai pluralisme dan toleransi. Agar pemahaman pluralisme dan toleransi dapat tertanam dengan baik pada peserta didik, maka perlu ditambahkan uraian tentang proses pembangunan masyarakat Madinah dalam materi keadaan masyarakat Madinah pasca Hijrahnya nabi yang dalam hal ini dapat ditelusuri pada Piagam Madinah. Sebagai salah satu produk sejarah umat Islam, Piagam Madinah merupakan bukti bahwa Nabi Muhammad berhasil memberlakukan nilai-nilai keadilan, prinsip kesetaraan, penegakan hukum, jaminan kesejahteraan bagi semua warga serta perlindungan terhadap kelompok minoritas. Beberapa ahli tentang sejarah Islam menyebut Piagam Madinah sebagai loncatan sejarah yang luar biasa. Dalam konstitusi itulah pertama kalinya dirumuskan ide-ide kemasyarakatan dan kenegaraan yang kini menjadi pandangan hidup modern di dunia, seperti kebebasan beragama, hak setiap kelompok untuk mengatur hidup sesuai dengan keyakinannya, kemerdekaan hubungan ekonomi antar golongan dan lain-lain.

Meskipun dalam tahapan konsep banyaknya agama dan keyakinan dalam nuansa multikultur diharapkan terjadi keharmonisan hubungan, akan tetapi dalam tahap implementasi masih banyak ketimpangan antara yang diharap dengan yang terjadi di lapangan. Dalam artian tidak semua orang mampu bersikap inklusif dalam hidup bersama di masyarakat yang majemuk. Walaupun secara normatif memang seorang yang beragama tidak dapat menghindarkan diri dari bingkai teologis tertentu, akan tetapi tidak berarti bersikap eksklusif dan menutup mata terhadap realitas sosial yang ada di sekelilingnya. Oleh karenanya diperlukan pemahaman yang komprehensif dan integral untuk mencairkan kebekuan teologis 
melalui interkoneksitas nilai-nilai humanis yang bernuansa kebersamaan atau berjalan bersama meskipun terdapat perberbedaan yang nyata.

\section{SIMPULAN}

Pendidikan multikultural diperlukan bangsa Indonesia untuk mengurangi terjadinya konflik horisontal antar masyarakat, baik karena perbedaan kultur, suku, adat, maupun agama. Pendidikan multikultural menekankan pada pembelajaran yang menghargai perbedaan, karena perbedaan itu merupakan hukum alam yang harus dihadapi bukan menjadi sumber perpecahan umat manusia. Pendidikan multikultur di Indonesia memang masih mencari bentuknya yang tepat dan efektif yang akan mencerahkan bagi semua peserta didik di Indonesia.

Pendidikan agama yang sering dituduh paling bertanggungjawab terhadap berbagai konflik yang banyak terjadi sebagai akumulasi perbedaan yang cukup tajam di Indonesia harus mampu menampilkan diri sebagai satu pembelajaran yang berwawasan multikultural. Hal ini dapat dilakukan melalui pilihan materi yang cocok atau bernuansa toleransi terhadap semua manusia. Dengan kata lain pendidikan agama mampu tampil atau menampilkan diri secara inklusif dalam bingkai kebersamaan meski jelas berbeda serta tidak menekankan perbedaan yang ada karena memang berbeda atau bahkan terjadi pembedaan karena semangat ideologi kelompok. Dengan demikian diperlukan pemahaman yang komprehensif dan integral terhadap substansi materi pendidikan agama serta cara pembelajaran yang efektif agar tercapai tujuan pendidikan yang bernuansa multikultur.

Walaupun semua orang menginginkan dan menyadari tentang penting dan gentingnya pendidikan multikultur di Indonesia sebagai upaya harmonisasi kehidupan berbangsa dan beragama, akan tetapi perilaku atau sikap sebagian besar masyarakat termasuk masyarakat terdidiknya terkadang kurang mencerminkan semangat multikultur. Oleh karena itu diperlukan upaya yang cermat dan tepat untuk menggugah kesadaran kolektif bangsa Indonesia agar tercipta keharmonisan abadi pada bangsa ini. Guru adalah salah satu komponen terpenting dalam pendidikan, oleh karenanya guru harus mampu menjadi model bagi terciptanya kehidupan multikultur yang terimplementasi dalam keseharian baik di sekolah 
maupun di masyarakat. Dikotomi antara nasionalis sekuler dan agama yang memberikan steriotipe bahwa seolah-olah seorang yang nasionalis kurang agamis dan sebaliknya yang agamanya kuat maka nasionalisme kurang haruslah segera dihilangkan agar tercipta keharmonisan di antara warga negara Indonsia.

\section{DAFTAR PUSTAKA}

Suhelmi, Ahmad.(1999). Soekarno versus Natsir. Jakarta: Darul Falah.

Banks, James A. (1989). Multicultural Education: Issues and Perspectives. Boston-London: Allyn and Bacon Press.

Banks, James A. (2007). Educating Citizens In Multicultural Society. Second edition. New York: Teachers College Columbia University.

Noeng Muhajir, (2000) Filsafat dan Teori Pendidikan. Yogyakarta: Pustaka Ilmu.

Tilaar, H.A.R. (2002) Perubahan Sosial dan Pendidikan: Pengantar Pedagogik Transformatif untuk Indonesia. Jakarta: PT. Grasindo.

Tilaar, H.A.R. (2004) Multikulturalisme Tantangan-tantangan Global Masa Depan dalam Transformasi Pendidikan Nasional. Jakarta: PT Grasindo.

Wieringa, Saskia Eleonora. (1999). The Politization of Gender Relations in Indonesia Women's Movement and Gerwani Until the New Order State. dalam Hersri Setiawan. Penghancuran Gerakan Perempuan di Indonesia, Jakarta : Garba Budaya.

Zamroni. (2007). Pendidikan dan Demokrasi dalam Transisi. Jakarta: PSAP Muhammadiyah.

Zamroni. (2011). Pendidikan Demokrasi pada Masyarakat Multikultural. Yogyakarta: Gavin Kalam Utama

Zamroni. (2010a). The Implementation of Multicultural Education. A reader. Yogyakarta: Graduate Program The State University of Yogyakarta.

Zamroni. (2010b). A Conception Frame-Work of Multicultural Teachers Education. A reader. Yogyakarta: Graduate Program The State University of Yogyakarta. 